\title{
Vanadium Compounds as Biocatalyst Models
}

\author{
Juliana E. Parente ${ }^{1}$ • Patricia A. M. Williams ${ }^{1}$ - Evelina G. Ferrer ${ }^{1}$ (I) \\ Received: 3 July 2019 / Accepted: 18 August 2019 / Published online: 24 August 2019 \\ (C) Springer Science+Business Media, LLC, part of Springer Nature 2019
}

\begin{abstract}
Peroxidovanadium(V) and oxidovanadium(IV) compounds have been tested as peroxidase-similar compounds. Their catalytic performance was tested on phenol red and pyrogallol substrates. Bromination kinetic studies revealed Michaelis-Menten behavior with respect to phenol red for both complexes. Catalytic efficiency is $\sim 10^{4} \mathrm{M}^{-1} \mathrm{~min}^{-1}$. Both vanadium complexes showed the capacity to oxidize pyrogallol, but only the oxidovanadium (IV) complex follows Michaelis-Menten kinetics with respect to this substrate $\left(K_{\mathrm{m}}=1.05 \times 10^{-3} \mathrm{M}\right)$. Peroxidovanadium(V) complex displayed a more complex mechanism, and further studies became necessary to elucidate it. The structure-activity relationship was also assessed.
\end{abstract}

Keywords Vanadium complexes $\cdot$ Biocatalyst models $\cdot$ Peroxidase-similar activity $\cdot$ Phenol red $\cdot$ Pyrogallol

\section{Introduction}

Peroxidases (EC 1.11.1.7) catalyze a diversity of chemical reactions involving the reduction of peroxides and oxidation of many phenolic substrates, metabolites, toxins, and inorganic compounds. These oxidoreductases are distributed in nature in microbes, animals, and plants. In particular, our interest is focused on vanadium-dependent peroxidases (VHPOs) [1]. Some of them were structurally well-characterized showing a similar active site in which the vanadium $(\mathrm{V})$ atom (vanadate anion) is bonded to nitrogen (from imidazole residue) and via hydrogen bonding to an $\mathrm{OH}$ group of histidine and water molecules. This active site is structurally modified under catalytic activity when a peroxide anion coordinates at the equatorial positions (Scheme 1). These kinds of enzymes, called haloperoxidases, are found in brown and red algae (Ascophyllum nodosum, Corallina officinalis) and also in fungi (Curvularia inaequalis) and received a great scientific interest because of the biochemical ability to catalyze in presence of $\mathrm{H}_{2} \mathrm{O}_{2}$, the oxidation of halides giving rise to halogenated derivatives: $\mathrm{X}^{-}+\mathrm{H}_{2} \mathrm{O}_{2}+\mathrm{H}^{+} \rightarrow \mathrm{RX}+$

Evelina G. Ferrer

evelina@quimica.unlp.edu.ar

1 Center of Inorganic Chemistry (CEQUINOR, CONICET-CICPBA-UNLP)-Department of Chemistry-Faculty of Exact Sciences, National University of La Plata, Boulevard 120 e/60 y 64, 1900, B1900AVV La Plata, Argentina
$\mathrm{H}_{2} \mathrm{O}(\mathrm{X}=$ halogen). Despite its potential high efficiency, industrial applications (pharmaceutical, biotechnological, and environmental protection) are limited due to its low physical stability and difficulty of production [2]. Because of these limitations, scientists are further interested in the development of model complexes. In this sense, vanadium coordination complexes have been recognized as efficient catalysts in several oxidation processes of industrial interest including the known capacity of simulation of haloperoxidases enzymes. Considering the presence of the vanadium atom in the active site of these enzymes, many oxidovanadium(V) and (IV) complexes having $\mathrm{O}$ and $\mathrm{N}$ atoms in their coordination sphere have been tested as models of this type of biological catalysts [3]. This development can afford an industrial method for the halogenation of several compounds without environmental contamination and the limitations of the large-scale production of enzymes. Moreover, the addition of a halogen atom in drugs is a strategic route to improve bioavailability and bioactivities. Our research group has been working for several years in the chemistry of vanadium-derivatives with functional organic ligands with the aim to develop biomimetic compounds. In this communication, we present results concerning the oxidovanadium(IV) and (V) complexes having the ability to simulate peroxidases. Their catalytic activities on bromination and oxidation of different compounds are determined by UV/Vis spectroscopy and the results are discussed based on the structural differences and compared with previous reports. Catalytic parameters were calculated with this objective. 


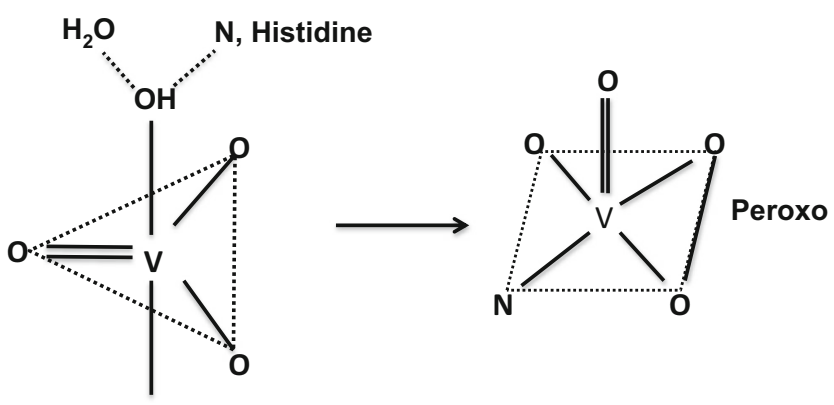

$\mathrm{N}$, Histidine

\section{Active site of the enzyme}

\section{Peroxo structure}

Scheme 1 General assumed active site of peroxidase enzyme and its peroxo form

\section{Materials and Methods}

All the chemicals used were from analytical grade and used as supplied. The peroxidovanadium(V) and oxidovanadium (IV) c o m p 1 e $\mathrm{x}$ e s

$\left(\left[\mathrm{VO}\left(\mathrm{O}_{2}\right)\left(\mathrm{C}_{7} \mathrm{H}_{6} \mathrm{NO}_{2}\right) \mathrm{H}_{2} \mathrm{O}\right] \cdot \mathrm{H}_{2} \mathrm{O}=\left[\mathrm{VO}\left(\mathrm{O}_{2}\right) \mathrm{LH}_{2} \mathrm{O}\right] \cdot \mathrm{H}_{2} \mathrm{O}\right.$, $\left[\mathrm{VO}\left(\mathrm{C}_{7} \mathrm{H}_{6} \mathrm{NO}_{2}\right)_{2} \mathrm{H}_{2} \mathrm{O}\right]=\left[\mathrm{VOL}_{2} \mathrm{H}_{2} \mathrm{O}\right]$; with $\mathrm{L}=\mathrm{C}_{7} \mathrm{H}_{6} \mathrm{NO}_{2}$, 4aminobenzoate, respectively) were both synthesized according to the literature [4]. The characterization of the catalysts has been carried out using a Bruker IFS 66 FTIRspectrophotometer in the $4000-400 \mathrm{~cm}^{-1}$ frequency range.

\section{Similar Peroxidase Activity}

\section{Bromoperoxidase Reaction}

The assay was performed according to the procedure published by Feng et al. [5]. The vanadium complexes were dissolved in DMF. The bromination activity experiments were performed at $25 \pm 0.5{ }^{\circ} \mathrm{C}$ and $\mathrm{pH} 5.8\left(\mathrm{NaH}_{2} \mathrm{PO}_{4}-\mathrm{Na}_{2} \mathrm{HPO}_{4}\right.$ buffer). Reactions were initiated with the presence of phenol red solution $(20 \mu \mathrm{M})$, an aliquot of $30 \% \mathrm{H}_{2} \mathrm{O}_{2}, \mathrm{KBr} 2 \mathrm{M}$, phenol red $(2.5-20 \mu \mathrm{M})$ and $24 \mu \mathrm{M}$ of the vanadium complexes. The spectral data recorded at 1-min intervals show the gradual disappearance of the peak at $443 \mathrm{~nm}$ due to the loss of phenol red and an increase in the absorbance of the peak at $592 \mathrm{~nm}$ due to the formation of the bromophenol blue product.

\section{Catalytic Oxidation of Pyrogallol}

The peroxidase-mimetic activity was determined using UVVis spectrophotometry. The absorbance increase at $420 \mathrm{~nm}$ (due to the formation of purpurogallin, $\varepsilon=2640 \mathrm{M}^{-1} \mathrm{~cm}^{-1}$ ) was monitored during $180 \mathrm{~min}$. The reaction was carried out in phosphate buffer (1 M, pH 7). The steady-state kinetics studies were performed by varying the concentration of pyrogallol (0.13-2 mM) while keeping a fixed concentration of
$\mathrm{H}_{2} \mathrm{O}_{2}(0.25 \mathrm{mM})$ and catalyst (V (IV) complex $=50 \mu \mathrm{M}-$ $1.8 \times 10^{-4} \mathrm{~g} ; \mathrm{V}(\mathrm{V})$ complex $\left.=50 \mu \mathrm{M}-1.35 \times 10^{-3} \mathrm{~g}\right)$.

\section{Evaluation of the Catalytic Parameters}

A treatment based on the Michaelis-Menten model developed for enzyme kinetics was performed. The values of the Michaelis-binding constant $\left(K_{\mathrm{m}}\right)$, maximum velocity $\left(V_{\max }\right)$, and rate constant for dissociation of substrates (i.e., turnover frequency, $k_{\text {cat }}$ ) were calculated from the Lineweaver-Burk graph (double reciprocal plot) of $1 /$ rate versus $1 /[\mathrm{S}]$, using the equation $1 / \mathrm{V}=\left(K_{\mathrm{m}} / V_{\max }\right)(1 /[\mathrm{S}])+1 / V_{\max }$. A control reaction carried out without the vanadium complex shows no change in the absorbance at $590 \mathrm{~nm}$. Triplicate determinations were performed in all the experiments.

\section{Results and Discussion}

The mimicking of the bromoperoxidase activity was evaluated according to the method proposed by Feng et al. [5]. In this method, the effect of the complexes on the bromination of phenol red (the organic substrate) is followed.

Phenol red $+\mathrm{X}^{-}+\mathrm{H}_{2} \mathrm{O}_{2}+\mathrm{H}^{+} \rightarrow$ Bromophenol blue $+\mathrm{H}_{2} \mathrm{O}$

$\mathrm{X}=\mathrm{Br}^{-} \mathrm{UV} /$ Vis band : $592 \mathrm{~nm}\left(\varepsilon=14500 \mathrm{M}^{-1} \mathrm{~cm}^{-1}\right)$

The addition of solutions of the vanadium complexes to the standard reaction of bromide (phosphate buffer $\mathrm{pH}=5.8$ ) containing phenol red produced a change in the color of the solution from yellow to blue. This was observed in the electronic UV-Vis spectra as an increment of the 592-nm band intensity (bromophenol blue product) and the corresponding decrease of the 443-nm band intensity due to the consumption of the phenol red (Fig. 1a, b, left). A control reaction was carried out without the vanadium complexes and showed no significant change in the absorbance at c.a. $590 \mathrm{~nm}$ (not shown). At first, the effect of catalyst's amount was evaluated using higher or smaller concentrations, but the reactions turned out to be too fast or without significant differences, respectively. For that reason, a concentration of $24 \mu \mathrm{M}$ of the catalyst was employed for the peroxidovanadium(V) and oxidovanadium(IV) complexes, and the reaction conditions were optimized working at fixed temperature, concentration of $\mathrm{H}_{2} \mathrm{O}_{2}$ and $\mathrm{pH}$ of the reaction. The effect of phenol red concentration was then evaluated (concentration range 5-7 to $20-30 \mu \mathrm{M})$.

The kinetic studies are shown in Fig. 1a, b, right. Both reactions showed saturation kinetics, and the MichaelisMenten kinetics model was applied. The values of the Michaelis-binding constant $\left(K_{\mathrm{m}}\right)$, maximum velocity $\left(V_{\max }\right)$, the rate constant for dissociation of substrates $\left(k_{\text {cat }}\right)$, percent 
(a)

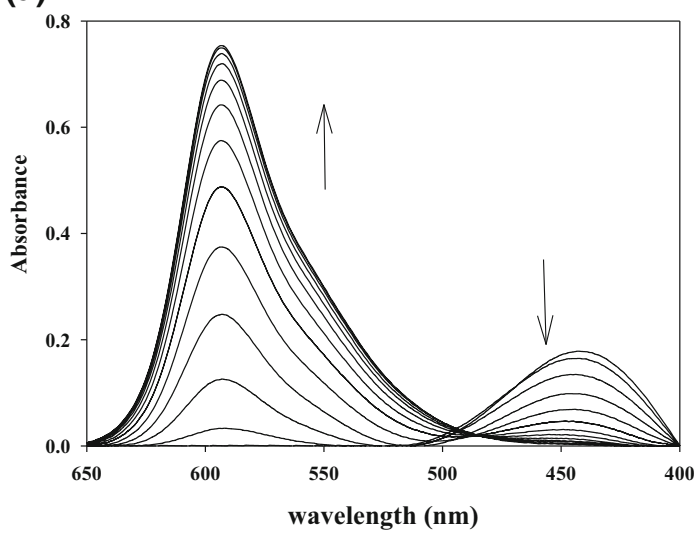

(b)

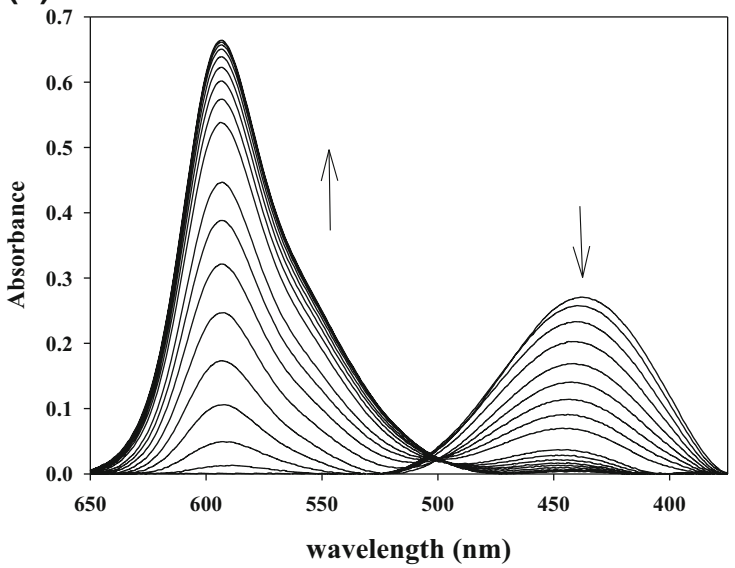

Fig. 1 Oxidative bromination of phenol red catalyzed by the vanadium complexes (left: UV/Vis spectra: progression over time of the phenol red and bromophenol blue product bands; right: Lineweaver-Burk graph: 1/V $\left.\left.=\left(K_{\mathrm{m}} / V_{\max }\right)(1 /[\mathrm{S}])+1 / V_{\max }\right)\right): \mathbf{a}\left[\mathrm{VO}\left(\mathrm{O}_{2}\right) \mathrm{LH}_{2} \mathrm{O}\right] \cdot \mathrm{H}_{2} \mathrm{O}, \mathbf{b} \mathrm{VOL}_{2} \mathrm{H}_{2} \mathrm{O}$.

conversion of phenol red together with the turn over number (TON) and the turn over frequency (TOF) are shown in Table 1. Chemical structures of the complexes are shown in Scheme 2. It is well known that $K_{\mathrm{m}}$ is indicative of the enzyme affinity toward its substrate and a lower value of $K_{\mathrm{m}}$ means a stronger affinity [10]. It can be seen that $K_{\mathrm{m}}$ value is lower for the oxidovanadium(IV) complex than for the peroxidovanadium complex. The catalytic efficiency $\left(k_{\mathrm{cat}} /\right.$ $K_{\mathrm{m}}$ ) values are in the same order of magnitude for both complexes. When a concentration of $10 \mu \mathrm{M}$ of phenol red is used, this complex produced a higher percentage of the conversion $(85.1 \%)$ as well as TON (0.77) and TOF (4.65) value at 10 min of the reaction time (Table 1).

There are experimental evidence in the literature related to metal coordination complexes, in particular, vanadium derivatives and some copper complexes, but working under different experimental conditions $(\mathrm{KBr}$, phenol red, and catalyst concentrations) and the solvent and the temperature varied in each case $[11,12]$. Different methodologies were employed, and different types of data were obtained. Li et al. demonstrated the reactivity of scorpionate
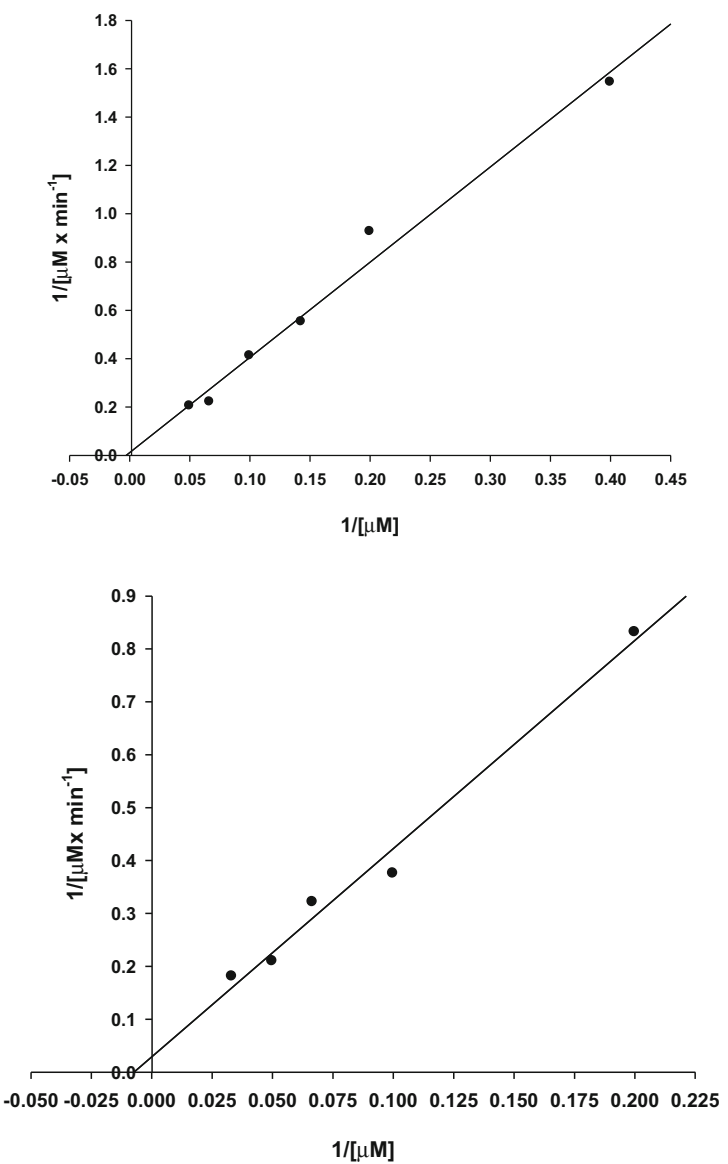

Spectral changes at 1-min intervals. Spectral data taken at $\mathrm{pH}=5.8$ (aqueous phosphate buffer), $[\mathrm{KBr}]=2 \mathrm{M}$, [phenol red] $=5$ to $20-30$ $\mu \mathrm{M},\left[\mathrm{VOL}_{2} \mathrm{H}_{2} \mathrm{O}\right]=\left[\mathrm{VO}\left(\mathrm{O}_{2}\right) \mathrm{LH}_{2} \mathrm{O}\right] \cdot \mathrm{H}_{2} \mathrm{O}=24 \mu \mathrm{M}$

oxidovanadium(IV)-carboxylate complexes showing only the modifications observed in the UV/Vis spectra [13], and similar studies were performed for oxidovanadiumpoly (pyrazolyl)boratecarboxylate complexes [14] and a series of oxidovanadium (IV) complexes containing poly (pyrazolyl) borate and organic carboxylic acid as ligands [15]. The literature also showed studies involving kinetic data for copper $[5,16]$ and vanadium complexes [12, 17-21]. These data were achieved by changing the catalyst concentration and obtaining linear plots in which the dependence of the absorbance with the reaction time has been graphed, and the reaction rate constant was calculated. Other investigations displayed the rate of bromine transfer for peroxidovanadium(V) [22] and peroxidotungsten(VI) [23] complexes. For those reasons, a direct comparison with these compounds is not appropriate. Due to these differences, in this short communication, a comparative analysis and discussion were focused on the reported $K_{\mathrm{m}}$ or $K_{\text {cat }}$ values obtained by Michaelis-Menten model, and the calculations were performed at different substrate concentrations. 
Table 1 Kinetic parameters for bromination of phenol red and pyrogallol by vanadium complexes and related compounds. $\mathrm{C}_{7} \mathrm{H}_{6} \mathrm{NO}_{2}$ : 4aminobenzoate anion

\begin{tabular}{|c|c|c|c|c|c|}
\hline Phenol red & $V_{\max }\left(\mathrm{M} \min ^{-1}\right)$ & $K_{\mathrm{m}}(\mathrm{M})$ & $k_{\mathrm{cat}}\left(\min ^{-1}\right)$ & $k_{\mathrm{cat}} / K_{\mathrm{m}}\left(\mathrm{M}^{-1} \min ^{-1}\right)$ & \\
\hline \multirow{7}{*}{$\begin{array}{l}{\left[\mathrm{VO}\left(\mathrm{O}_{2}\right)\left(\mathrm{C}_{7} \mathrm{H}_{6} \mathrm{NO}_{2}\right) \mathrm{H}_{2} \mathrm{O}\right] \cdot \mathrm{H}_{2} \mathrm{O}} \\
\text { Pentagonal pyramid }\end{array}$} & $8.34 \pm 0.10 \times 10^{-5}$ & $3.29 \pm 0.05 \times 10^{-4}$ & 3.48 & $1.05 \times 10^{4}$ & This work \\
\hline & ${ }^{\mathrm{a}}$ Conversion (\%) & phenol red $(\mu \mathrm{M})$ & $\mathrm{TON}^{\mathrm{b}}$ & $\operatorname{TOF}^{\mathrm{c}}\left(\mathrm{h}^{-1}\right)$ & \\
\hline & 81.6 & 7 & 0.52 & 3.10 & \\
\hline & 80.5 & 10 & 0.69 & 4.15 & \\
\hline & 80.0 & 15 & 1.30 & 7.81 & \\
\hline & 74.5 & 20 & 1.34 & 8.05 & \\
\hline & $V_{\max }\left(\mathrm{M} \min ^{-1}\right)$ & $K_{\mathrm{m}}(\mathrm{M})$ & $k_{\text {cat }}\left(\min ^{-1}\right)$ & $k_{\text {cat }} / K_{\mathrm{m}}\left(\mathrm{M}^{-1} \min ^{-1}\right)$ & \\
\hline \multirow{8}{*}{$\begin{array}{l}\text { cis- }\left[\mathrm{VO}\left(\mathrm{C}_{7} \mathrm{H}_{6} \mathrm{NO}_{2}\right)_{2} \mathrm{H}_{2} \mathrm{O}\right] \\
\text { Square pyramidal geometry }\end{array}$} & $3.44 \pm 0.04 \times 10^{-5}$ & $1.35 \pm 0.02 \times 10^{-4}$ & 1.43 & $1.06 \times 10^{4}$ & This work \\
\hline & ${ }^{\mathrm{a}}$ Conversion $(\%)$ & phenol red $(\mu \mathrm{M})$ & $\mathrm{TON}^{\mathrm{b}}$ & $\operatorname{TOF}^{\mathrm{c}}\left(\mathrm{h}^{-1}\right)$ & \\
\hline & 89.2 & 5 & 0.31 & 1.84 & \\
\hline & 85.1 & 10 & 0.77 & 4.65 & \\
\hline & 71.6 & 15 & 1.02 & 6.14 & \\
\hline & 63.1 & 20 & 1.22 & 7.29 & \\
\hline & 28.1 & 30 & 1.22 & 7.32 & \\
\hline & $V_{\max }\left(\mathrm{M} \min ^{-1}\right)$ & $K_{\mathrm{m}}(\mathrm{M})$ & $k_{\text {cat }}\left(\min ^{-1}\right)$ & $k_{\text {cat }} / K_{\mathrm{m}}\left(\mathrm{M}^{-1} \min ^{-1}\right)$ & \\
\hline$\left[\mathrm{Et}_{3} \mathrm{NH}\right]\left[\mathrm{VO}_{2}(\text { sox-pydx })\right]^{*}$ & $4.39 \times 10^{-3}$ & $4.40 \times 10^{-4}$ & & & [6] \\
\hline $\begin{array}{l}\text { Square pyramidal geometry } \\
{\left[\mathrm{Cu}\left(\mathrm{C}_{4} \mathrm{H}_{5} \mathrm{~N}_{2} \mathrm{~S}\right)_{2} \mathrm{Cl}_{2}\right] \cdot 2 \mathrm{H}_{2} \mathrm{O}} \\
\text { Planar geometry }\end{array}$ & $3.48 \times 10^{-7}$ & $1.34 \times 10^{-3}$ & 0.14 & 104.5 & [7] \\
\hline $\begin{array}{l}{\left[\mathrm{Cu}\left(\mathrm{C}_{8} \mathrm{H}_{10} \mathrm{~N}_{4} \mathrm{~S}\right) \mathrm{SO}_{4} \mathrm{H}_{2} \mathrm{O}\right]^{* *}} \\
\text { Square pyramidal geometry }\end{array}$ & $6.45 \times 10^{-6}$ & $11.76 \times 10^{-6}$ & 6.45 & $5.48 \times 10^{5}$ & [7] \\
\hline Pyrogallol & $V_{\max }\left(\mathrm{M} \min ^{-1}\right)$ & $K_{\mathrm{m}}(\mathrm{M})$ & $k_{\text {cat }}\left(\min ^{-1}\right)$ & $k_{\text {cat }} / K_{\mathrm{m}}\left(\mathrm{M}^{-1} \min ^{-1}\right)$ & \\
\hline \multirow{8}{*}{$\begin{array}{l}\left.\text { cis-[VO }\left(\mathrm{C}_{7} \mathrm{H}_{6} \mathrm{NO}_{2}\right)_{2} \mathrm{H}_{2} \mathrm{O}\right] \\
\text { Square pyramidal geometry }\end{array}$} & $3.55 \pm 0.05 \times 10^{-6}$ & $1.05 \pm 0.02 \times 10^{-3}$ & 0.071 & 67.62 & This work \\
\hline & Purpurogallin $(\mu \mathrm{M})$ at $40 \mathrm{~min}$ & Pyrogallol (mM) & $\mathrm{TON}^{\mathrm{b}}$ & $\operatorname{TOF}^{\mathrm{c}}\left(\mathrm{h}^{-1}\right)$ & \\
\hline & 16.2 & 0.13 & 0.32 & 0.97 & \\
\hline & 22.9 & 0.26 & 0.46 & 5.50 & \\
\hline & 47.6 & 0.52 & 0.95 & 2.86 & \\
\hline & 74.8 & 1.4 & 1.50 & 4.49 & \\
\hline & 116 & 2.0 & 2.32 & 6.95 & \\
\hline & $V_{\max }\left(\mathrm{M} \mathrm{min} \min ^{-1}\right)$ & $K_{\mathrm{m}}(\mathrm{M})$ & $k_{\text {cat }}\left(\min ^{-1}\right)$ & $k_{\text {cat }} / K_{\mathrm{m}}\left(\mathrm{M}^{-1} \min ^{-1}\right)$ & \\
\hline $\begin{array}{l}\text { PS-[VO }(\mathrm{OMe})(\text { hap-iah) } \\
\text { Square pyramidal geometry }\end{array}$ & $3.87 \times 10^{-6}$ & & $4.79 \times 10^{-3}$ & & [8] \\
\hline $\begin{array}{l}\text { PS-[VO (sal-dahp)] }]^{\# \#} \\
\text { Square pyramidal geometry. }\end{array}$ & $9.20 \times 10^{-7}$ & & $3.62 \times 10^{-3}$ & & [9] \\
\hline
\end{tabular}

${ }^{\text {a }}$ Percentage conversion of phenol red (average of three different trials using fresh catalyst each time)

${ }^{\mathrm{b}}$ TON $=$ Turn over number (number of moles of product/number of moles of catalyst)

${ }^{\mathrm{c}} \mathrm{TOF}=$ turn over frequency $\left(\mathrm{h}^{-1}\right.$, moles of substrate converted per mole of catalyst per hour). Values calculated at 10 min of the time of the reaction for phenol red and at $40 \mathrm{~min}$ for pyrogallol

${ }^{*}\left[\mathrm{Et}_{3} \mathrm{NH}\right]\left[\mathrm{VO}_{2}(\right.$ sox-pydx $\left.)\right]=\left[\mathrm{C}_{6} \mathrm{H}_{16} \mathrm{~N}\right]\left[\mathrm{VO}_{2}\left(\mathrm{C}_{10} \mathrm{H}_{10} \mathrm{~N}_{4} \mathrm{O}_{4}\right]\right.$ using tetra-N-butylammonium bromide, data from ref [6]

** Data for copper complexes were taken from ref [7]

\# PS-[VO $(\mathrm{OMe})($ hap-iah) = polymer grafted oxidomethoxidovanadium $(\mathrm{V})$ complex [8]

\#\# PS-[VO (sal-dahp)]: polymer grafted oxidovanadium(IV) Schiff base complex derived from salicylaldehyde and 1,3-diamino-2-hydroxypropane [9]

It can be noted that the calculated $K_{\mathrm{m}}$ values for the complexes are similar to the calculated for dioxidovanadium(V) complex derived from oxamohydrazide and pyridoxal $\left(\left[\mathrm{Et}_{3} \mathrm{NH}\right]\left[\mathrm{VO}_{2}(\right.\right.$ sox-pydx) $]$, Table 1$)$ even though tetra-Nbutylammonium bromide instead $\mathrm{KBr}$ and a different $\mathrm{pH}$ value of the buffer were used [6]. Despite those differences, the anionic part of the complex has a square pyramidal geometry with the vanadium(V) atom in a dioxidovanadium unity in a similar structural arrangement to oxidovanadium(IV) complex [4] (Table 1). Recently, we 
Scheme 2 Schematic representation of the structures of the complexes: a $\left[\mathrm{VO}\left(\mathrm{O}_{2}\right)(4-\right.$ aminobenzoate) $\left.\mathrm{H}_{2} \mathrm{O}\right] \cdot \mathrm{H}_{2} \mathrm{O}$, b [VO(4-aminobenzoate) $\left.)_{2} \mathrm{H}_{2} \mathrm{O}\right], \mathbf{c}$ $\left[\mathrm{VO}_{2}(\text { sox-pydx })\right]^{-}, \mathbf{d}[\mathrm{VO}$ (OMe)(hap-iah)], e [VO (saldahp)], $\mathbf{f}$

$\left[\mathrm{Cu}\left(\mathrm{C}_{4} \mathrm{H}_{5} \mathrm{~N}_{2} \mathrm{~S}_{2} \mathrm{Cl}_{2}\right] \cdot 2 \mathrm{H}_{2} \mathrm{O}\right.$, and $\mathbf{g}$ $\left[\mathrm{Cu}\left(\mathrm{C}_{8} \mathrm{H}_{10} \mathrm{~N}_{4} \mathrm{~S}\right) \mathrm{SO}_{4} \mathrm{H}_{2} \mathrm{O}\right]$

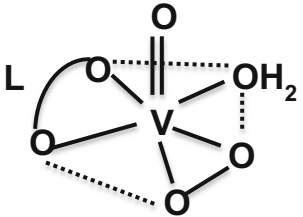

(a) $\left[\mathrm{VO}\left(\mathrm{O}_{2}\right)(4\right.$-aminobenzoate $\left.) \mathrm{H}_{2} \mathrm{O}\right] \cdot \mathrm{H}_{2} \mathrm{O}$

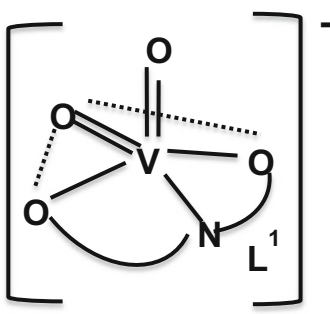

(c) $\left[\mathrm{VO}_{2}(\right.$ sox-pydx)] $L^{1}=$ soxH-pydxH

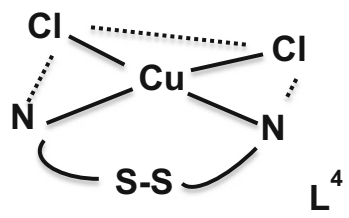

(f) $\left[\mathrm{Cu}\left(\mathrm{C}_{4} \mathrm{H}_{5} \mathrm{~N}_{2} \mathrm{~S}\right)_{2} \mathrm{Cl}_{2}\right] \cdot 2 \mathrm{H}_{2} \mathrm{O}$ $L^{4}=\left(\mathrm{C}_{4} \mathrm{H}_{5} \mathrm{~N}_{2} \mathrm{~S}\right)_{2}$

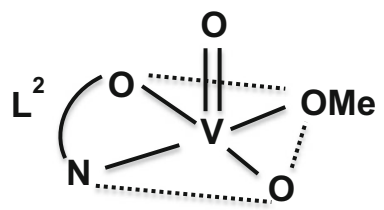

(d) [VO(OMe)(hap-iah)]

$L^{2}=H_{2}$ hap-iah, Me=methanol<smiles>COP(=O)(O)OC1COCCO1</smiles>

(b) [VO(4-aminobenzoate) $\left.{ }_{2} \mathrm{H}_{2} \mathrm{O}\right]$

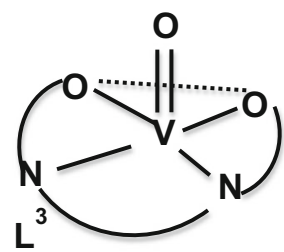

(e) [VO(sal-dahp)] $L^{3}=H_{3}$ sal-ahp

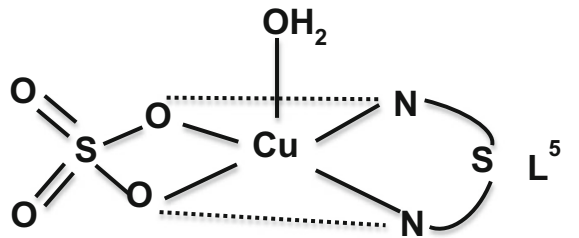

(g) $\left[\mathrm{Cu}\left(\mathrm{C}_{8} \mathrm{H}_{10} \mathrm{~N}_{4} \mathrm{~S}\right) \mathrm{SO}_{4} \mathrm{H}_{2} \mathrm{O}\right]$ $L^{5}=\mathrm{C}_{8} \mathrm{H}_{10} \mathrm{~N}_{4} \mathrm{~S}$ studied two copper complexes with ligands derived from methimazol in the same experimental conditions (Table 1) [7]. It can be seen, in coincidence with the dioxidovanadium(V) complex [6] that the most efficient catalyst was the copper complex with square pyramidal geometry (higher $k_{\text {cat }} / K_{\mathrm{m}}$ ). Possibly this geometry, irrespective of the ligands favors the catalysis of bromination of phenol red. Nevertheless, further studies are still necessary to elucidate all the variables that may influence the kinetic behavior. Anyway, in this work, a high percentage of substrate conversion was achieved in a very short time working with the vanadium complexes which, in conjunction with higher catalytic efficiencies, suggested that the compounds behaved as good bromoperoxidase-mimics.

The efficiency to transform pyrogallol to purpurogallin was chosen as an additional model reaction.

Pyrogallol $+\mathrm{H}_{2} \mathrm{O}_{2} \rightarrow$ Purpurogallin UV/Vis band

$$
\text { : } 420 \mathrm{~nm}\left(\varepsilon=2640 \mathrm{M}^{-1} \mathrm{~cm}^{-1}\right)
$$

To investigate the kinetic parameters of the complexes, the time-dependent absorbance evolution at $420 \mathrm{~nm}$ in the presence of different concentrations of pyrogallol $(0.13,0.26$, $0.525,1.4$, and $2 \mathrm{mM}$ ), and fixed concentrations of $\mathrm{H}_{2} \mathrm{O}_{2}$ and catalyst $(50 \mu \mathrm{M})$ was evaluated. These experimental conditions were found to be the best in order to get reproducible data.
According to Michaelis-Menten kinetics model, it was noted that the oxidovanadium(IV) complex follows saturation kinetics. The reaction is first order at low-substrate (pyrogallol) concentration (linear plot) while at higher concentrations of the catalyst became saturated with the substrate and the reaction is zero order (Fig. 2a). Therefore, this complex follows a Michaelis-Menten behavior towards pyrogallol (Fig. 2b). On the contrary, this behavior was not observed for the peroxidovanadium $(\mathrm{V})$ complex, and in this case, it was not possible to perform calculations of the kinetic parameters. This complex is able to act on pyrogallol but, unfortunately, the mechanism seemed to be more complex than a simple Michaelis-Menten model.

For the oxidovanadium(IV) complex, the LineweaverBurk plot (Fig. 2b) showed the following kinetic parameters: $K_{\mathrm{m}}=1.05 \times 10^{-3} \mathrm{M}, \mathrm{V}_{\max }=3.55 \times 10^{-6} \mathrm{M} \times \min ^{-1}, K_{\mathrm{cat}}=$ $0.071 \mathrm{~min}^{-1}$, and $K_{\text {cat }} / K_{\mathrm{m}}=67.62 \mathrm{M}^{-1} \mathrm{~min}^{-1}$. Related to the product, the best values were obtained for the lower pyrogallol concentrations $(0.13$ and $0.26 \mathrm{mM})$ being a maximum of $60 \%$ (180 min of the reaction time). In addition, the TON and TOF values denote moderate activity considering that they were calculated after $40 \mathrm{~min}$ of the start of the reaction.

Although to a lesser extent, the information in the literature related to catalytic oxidation of pyrogallol by metal coordination complexes is varied (like for the phenol red substrate) and does not allow us to make a direct comparison of the results. For instance, the oxidation of pyrogallol red by $\mathrm{H}_{2} \mathrm{O}_{2}$ in 
(a)

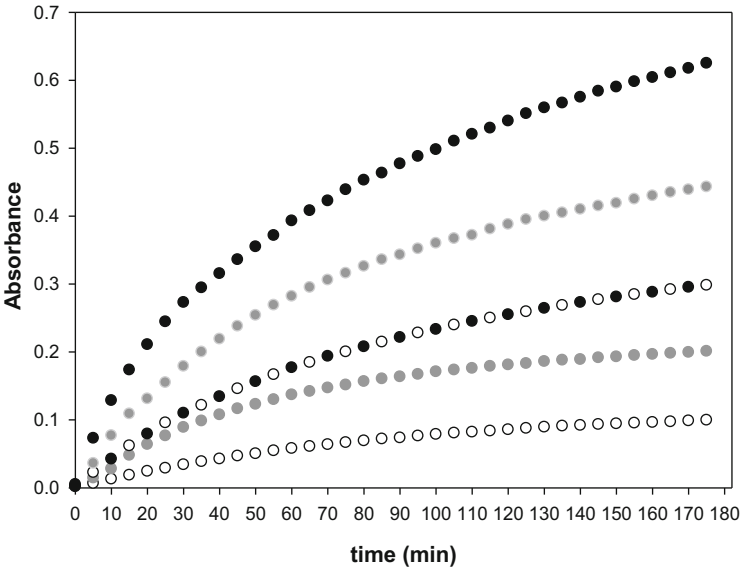

Fig. 2 Oxidative bromination of pyrogallol catalyzed by $\left[\mathrm{VOL}_{2} \mathrm{H}_{2} \mathrm{O}\right]$. a Abs vs time graph, increasing pyrogallol concentrations from 0.13 to 2 $\mathrm{mM}$, b Lineweaver-Burk graph: $\left.1 / \mathrm{V}=\left(K_{\mathrm{m}} / V_{\max }\right)(1 /[\mathrm{S}])+1 / V_{\max }\right)$.

presence of $\mathrm{Mo}(\mathrm{VI})\left(\mathrm{MoO}_{3}\right)$ has been studied with a fix-time method, and the influences of the ionic strength and temperature were analyzed on the reaction rate [24] and also dioxidomolybdenum (VI) complexes having tripodal tetradentate ligands were investigated, and their activity were compared with those of the transhydroxylases [25]. There are examples of the determination of peroxidase activity for the following complexes: a water-soluble cationic Fe(III)-porphyrin [26], dinuclear copper(II) and cobalt(II) complexes [27] and 8-hydroxyquinoline-aluminum complex (for the detection of pyrogallol in tomato) [28].

Comparison were afforded with the reported activities for other oxidovanadium(V) [8] and (IV) [9] complexes (Table 1) suggesting that cis- $\left[\mathrm{VO}\left(\mathrm{C}_{7} \mathrm{H}_{6} \mathrm{NO}_{2}\right)_{2} \mathrm{H}_{2} \mathrm{O}\right]$ behaved as a better catalyst than the polymers grafted oxidovanadium compounds having a larger $k_{\text {cat }}$ value hence implying a higher number of molecules of substrate converted in product per minute.

\section{Conclusions}

Peroxidovanadium(V) and oxidovanadium(IV) metal complexes bearing 4-aminobenzoate ligand have been tested as peroxidase-similar compounds. Both complexes resulted active as catalysts being capable to convert in an efficient manner the organic substrate phenol red to bromophenol blue $\left(K_{\mathrm{m}} \sim 10^{-4} \mathrm{M}, k_{\mathrm{cat}}=1.5-3.5 \mathrm{~min}^{-1}\right)$ with similar catalytic efficiency. The efficiency to transform pyrogallol to purpurogallin was also proved, but only the oxidovanadium(IV) complex followed a Michaelis-Menten kinetics behavior respect to pyrogallol. From the experimental data and the comparison with other oxidovanadium compounds, a correlation of the structure-activity was analyzed assuming a better catalytic behavior on phenol red for the square pyramidal geometry. The activity of the structural related copper complex resulted (b)

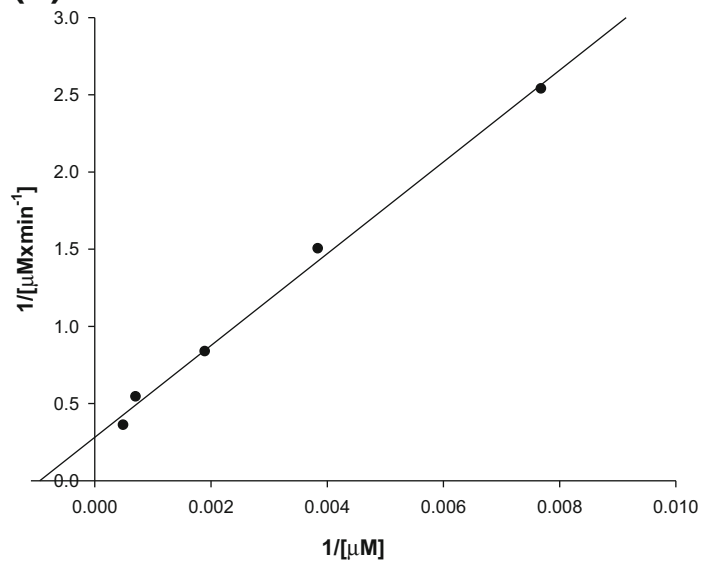

Spectral data for: pyrogallol $(0.13-2 \mathrm{mM}), \mathrm{H}_{2} \mathrm{O}_{2}(0.25 \mathrm{mM})$, $\left[\mathrm{VOL}_{2} \mathrm{H}_{2} \mathrm{O}\right]=50 \mu \mathrm{M}$, and $\mathrm{pH}=7$

somehow greater. Oxidation of pyrogallol was better achieved by the square pyramidal oxidovanadium(IV) complex in comparison to the polymer grafted square pyramidal oxidovanadium(V).

Funding Information This work was supported by the Consejo Nacional de Investigaciones Científicas y Técnicas (CONICET, PIP 0611), Agencia Nacional de Promoción Científica y Tecnológica (ANPCyT, PICT16-1814), and Universidad Nacional de La Plata (UNLP, X777) of Argentina. EGF is a Research Fellow of CONICET. JEP and PAMW are Research Fellows of Comisión de Investigaciones Científicas de la Provincia de Buenos Aires (CICPBA) Argentina.

\section{Compliance with Ethical Standards}

Conflict of Interest The authors declare that they have no conflict of interest.

\section{References}

1. Bansal N, Kanwar SS (2013) Peroxidase(s) in environment protection. Sci World J 2013:1-9

2. Wischang D, Brucher O, Hartung J (2011) Bromoperoxidases and functional enzyme mimics as catalysts for oxidative brominationa sustainable synthetic approach. Coord Chem Rev 255:2204-2217

3. Sutradhar M, Martins LMDRS, Guedes da Silva MFC, Pombeiro AJL (2015) Coord Chem Rev 215:301-302 200-239

4. Parente JE, Naso LG, Jori K, Franca CA, da Costa FAM, Williams PAM, Ferrer EG (2019) In vitro experiments and infrared spectroscopy analysis of acid and alkaline phosphatases inhibition by vanadium complexes. New J Chem. https://doi.org/10.1039/ C9NJ01638D

5. Feng XD, Zhang R, Wang XY, Zhang XX, Wang JX, Xing YH, Sun LX (2015) Mimicing bromoperoxidase for copper complexes: synthesis, structures and properties of $\mathrm{Cu}$ (II)-triazine pyrazolyl complex. Polyhedron 90:69-76

6. Das C, Adak P, Mondal ST, Sekiya R, Kuroda R, Gorelsky SI, Chattopadhyay SK (2014) Synthesis, characterization, x-ray crystal structure, DFT calculations, and catalytic properties of a 
dioxidovanadium $(\mathrm{V})$ complex derived from oxamohydrazide and pyridoxal: a model complex of vanadate-dependent bromoperoxidase. Inorg Chem 53:11426-11437

7. Martini N, Parente JE, D' Alessandro F, Rey M, Rizzi A, Williams PAM, Ferrer EG (2019) Potential bio-protective effect of copper compounds: mimicking SOD and peroxidases enzymes and inhibiting acid phosphatase as a target for anti-osteoporotic chemotherapeutics. Mol Biol Rep 46:867-885

8. Maurya MR, Kumar N, Chaudhary N (2015) A polymer grafted oxidomethoxidovanadium(V) complex of an $\mathrm{ONO}$ donor ligand mimicking peroxidase activity. Polyhedron 97:103-111

9. Maurya MR, Chaudhary N, Avecilla F, Correia I (2015) Mimicking peroxidase activity by a polymer-supported oxidovanadium(IV) Schiff base complex derived from salicylaldehyde and 1,3diamino-2-hydroxypropane. J Inorg Biochem 147:181-192

10. Zhao K, Gu W, Zheng S, Zhang C, Xian Y (2015) SDS-MoS nanoparticles as highly-efficient peroxidase mimetics for colorimetric detection of $\mathrm{H}_{2} \mathrm{O}_{2}$ and glucose. Talanta 141:47-52

11. Chen C, Sun Q, Ren D-X, Zhang R, Bai F-Y, Xing Y-H, Shi Z (2013) Bromoperoxidase mimic as catalysts for oxidative bromination-synthesis, structures and properties of the diversified oxidation state of vanadium (III, IV and V) complexes with pincer Nheterocycle ligands. CrystEngComm 15:5561-5573

12. Feng XD, Zhang XX, Wang ZN, Song J, Xing YH, Bai FY (2016) Mimicking vanadium haloperoxidases: vanadium (III)-carboxylic acid complexes and their application in $\mathrm{H}_{2} \mathrm{O}_{2}$ detection. New $\mathrm{J}$ Chem 40(2): 1222-1229

13. Li Z-P, Xing Y-H, Cao Y-Z, Zeng X-Q, Ge M-F, Niu S-Y (2009) Synthesis, structure and properties of a series of scorpionate oxovanadium (IV)-carboxylate complexes. Polyhedron 28:865871

14. Li Z-P, Xing Y-H, Wang C-G, Li J, Cao Y-Z, Zeng X-Q, Ge M-F, Niu S-Y (2009) Haloperoxidaselike compounds: synthesis, structure and properties of two new oxidovanadiumpoly (pyrazolyl)boratecarboxylate complexes. Z Anorg Allg Chem 635:2601-2607

15. Zhao H-Y, Zhang Y-H, Xing Y-H, Li Z-P, Cao Y-Z, Ge M-F, Zeng X-Q, Niu S-Y (2009) A series of oxo-vanadium (IV) complexes containing mixed ligands of poly (pyrazolyl) borate and organic carboxylic acid: synthesis, structural characterization and primary study of bromination reaction activities. Inorg Chim Acta 362: $4110-4118$

16. Wang J-X, Wang X, Hou Y-N, Feng X-D, Sun L-X, Shi Z, Wang C, Xing Y-H (2015) Synthesis, structures and catalytic studies of new copper (II) complexes with arene-linked pyrazolyl methane ligands. J Coord Chem 68:1544-1558

17. Feng XD, Zhang R, Wang XY, Zhang XX, Wang JX, Xing YH, Sun LX (2011) Mimicing bromoperoxidase for copper complexes: synthesis, structures and properties of $\mathrm{Cu}$ (II)-triazine pyrazolyl complex. Inorg Chim Acta 368:223-230

18. Saha U, Mukherjea KK (2015) Development of multifunctional biomimicking Lcysteine based oxovanadium(IV) complex: synthesis, DFT calculations, bromo-peroxidation and nuclease activity. RSC Adv 5:94462-94473

19. Zhang R, Liu J, Chen C, Xing Y-H, Guan Q-L, Hou Y-N, Wanga X, Zhang X-X, Bai F-Y (2013) Synthesis, structures and properties of the catalytic bromination reaction of a series of novel scorperate oxidovanadium complexes with the potential detection of hydrogen peroxide in water. Spectrochim. Acta Part A: Mol Biomol Spectrosc 115:476-482

20. Chen C, Bai F-Y, Zhang R, Song G, Shan H, Xing N, Xing Y-H (2013) Synthesis, structure, and catalytic bromination of supramolecular oxovanadium complexes containing oxalate. J Coord Chem 66:671-688

21. Zhang R, Zhang X-X, Bai F-Y, Chen C, Guana Q-L, Hou Y-N, Wang X, Xing Y-H (2015) Dinuclear vanadium complexes with rigid phenylpolycarboxylate ligands: synthesis, structure, and catalytic bromination reaction with potential detection of hydrogen peroxide. J Coord Chem 68:1613-1628

22. Sarmah S, Kalita D, Hazarika P, Borah R, Islam NS (2004) Synthesis of new dinuclear and mononuclear peroxovanadium(V) complexes containing biogenic co-ligands: a comparative study of some of their properties. Polyhedron 23:1097-1107

23. Hazarika P, Kalita D, Sarmah S, Borah R, Islam NS (2006) New oxo-bridged dinuclear peroxotungsten (VI) complexes: synthesis, stability and activity in bromoperoxidation. Polyhedron 25:35013508

24. Iloukhani H, Rajali F, Zeini A (2001) Thermodynamic and kinetic studies on oxidation of pyrogallol red by hydrogen peroxide in the absence and presence of molybdenum (VI). Phys Chem Liq 39: $239-247$

25. Maurya MR, Uprety B, Avecilla F (20 16) Dioxidomolybdenum(VI) complexes of tripodal tetradentate ligands for catalytic oxygen atom transfer between benzoin and dimethyl sulfoxide and for oxidation of pyrogallol. Eur J Inorg Chem 4802-4813

26. Yamaguchi H, Tsubouchi K, Kawaguchi K, Horita E, Harada A (2004) Peroxidase activity of cationic metalloporphyrin-antibody complexes. Chem Eur J 10:6179-6186

27. Qiu J-H, Liao Z-R, Meng X-G, Zhu L, Wang Z-M, Yu K-B (2005) Crystal structures and polyphenol oxidase activities of dinuclear copper(II) and cobalt(II) complexes with $\mathrm{N}, \mathrm{N}, \mathrm{N}^{\prime}, \mathrm{N}^{\prime}$-tetrakis $\left(2^{\prime}\right.$ benzimidazolylmethyl)-1,4-diethylene amino glycol ether (EGTB). Polyhedron 24:1617-1623

28. Bao A, Xiao N, Zhu Y, Xin S, Zhang H (2015) The electrochemical catalytic behavior of pyrogallol at an 8-hydroxyquinolinealuminum complex modified carbon paste electrode and its detection in tomato. RSC Adv 5:12710-12716

Publisher's Note Springer Nature remains neutral with regard to jurisdictional claims in published maps and institutional affiliations. 